\title{
IMPERATIVELE ŞI PROVOCĂRILE MISIUNII ORTODOXE ACTUALE: CONFRUNTAREA CU SECULARISMUL ŞI RE-DESCOPERIREA DIMENSIUNII LITURGICE A PERSOANEI ŞI A VIETII UMANE
}

Ciprian Streza*

\begin{abstract}
The Orthodox Church is first and foremost a liturgical Church. The Eucharistic Liturgy sits at the centre of the Church life, as all the endeavours of the ecclesiastical pleroma stem from the Eucharistic celebration. The Holy Liturgy, the heartbeat of the Orthodox Christian spirituality, dynamizes the Church within Her inner and outer mission in the modern secular world. To overcome the temptations of the modern secularized society, the Christians of the 21 st century are called to rediscover their liturgical vocation and the true meaning and power of the Orthodox Worship with all his eschatological, ecclesiological, ascetical and cosmic dimensions and content.
\end{abstract}

Keywords: Church, Mission, Liturgy, Worship, Secularism

Într-o modernitate a contrastelor puternice, a dezbinărilor profunde, a relativismul individualist, a valorizării excesive a vieții biologice, considerată ca unica formă de împlinire a existenței umane ce se rezumă aproape exclusiv la planul material, într-o lume în care valorile spiritualității creștine sunt tot mai contestate, Biserica este chemată la un nou tip de pastorație. Discursul ei misionar trebuie să fie unul viu, dinamic, relevant pentru omul contemporan, urmărind iniţierea lui în tainele vieții viitoare şi în gustarea din harul Împărăției cerurilor. În acest sens un rol major revine lucrării pastoral misionare a Bisericii care este chemată la o ieşire din „captivitatea babilonică”

*PhD, Professor, Faculty of Theology “Andrei Șaguna” Sibiu, Romania. 
a stereotipurilor, a limbajului sec, a rutinei şi a lipsei de relevanță pentru realitătaile societății contemporane.

Lumea modernă consumistă se impune şi se afirmă tot mai mult în conştiința fiecărei persoane cu o nouă concepție despre lume şi viață, care chestionează toate valorile tradiţionale creştine şi care prin se afirmă prin crearea unor noi curente de opinie total opuse etosului creştin românesc. Noua lume industrializată şi excesiv urbanizată îşi afirmă crezul cu tărie: believing without belonging ${ }^{1}$, adică descătuşarea de orice apartenența la vreo confesiune şi refuzul oricărei forme de religie instituționalizată, în favoarea făuririi unei religii proprii este ceea ce va defini religiozitatea omului secolului XXI.

Cei care aderă la această nouă confesiune „neconfesională” sunt cei pe care birocrația marilor corporații şi stresul unei existențe fundamentate doar pe materie, $i-a$ transformat în indivizi anonimi care au uitat şi care nu mai au puterea relaționării personale atât față de Dumnezeu cât şi faţă de semeni. Creştinismul presupune tocmai această relaţionare personală şi de aceea el este din ce în ce mai mult marginalizat şi înlocuit cu o pseudo-religie, cu un „creştinism mutant”: „Viaţa religioasă, remarcă Grace Davie, ca şi multe alte trăsături ale societății post-industriale şi post-moderne, nu este atât de mult pe cale să dispară cât să sufere mutații majore, căci în mod cert căutarea sacrului va continua, dar în forme cu totul noi mult diferite decât cele ale trecutului.."

Studii moderne de sociologie arată că ceea ce se petrece din punct de vedere religios în societăţile post moderne este un fenomen unic şi cu totul nou. Se vorbeşte tot mai mult despre o „ieşire din religie" dar aceasta nu înseamnă ieşire din credința religioasă, ci ieşirea dintr-o lume în care credința este structurantă, dintr-o lume care este bazată pe ierarhie şi pe relații interpersonale. „Ieşirea din

${ }^{1}$ Grace Davie, Religion in Britain Since 1945: Believing Without Belonging, Oxford, Basil Blackwell, 1994, p. 226.

${ }^{2}$ Ibidem, p. 198. Autoarea cărții citează o statistică din Marea Britanie care arată că în acea țară doar $60 \%$ din populație este nominal creștină, însă doar $14 \%$ s-a declarat că aparține unui cult creştin anume (p. 143). 
religie reprezintă trecerea într-un univers în care religiile continuă să existe, dar în interiorul unei forme politice şi al unei ordini colective pe care nu le mai determină... Ieşirea din religie este, în adâncul ei, preschimbarea vechiului element religios în altceva decât religia... o recompunere de ansamblu a lumii umane prin re-absorbție, o retopire şi reelaborare a ceea ce a purtat în ea, milenii la rând, a chipului alteritătii ei religioase..."3.

Într-o astfel de situație şi un astfel de context, Biserica Ortodoxă este chemată să îşi afirme vocația ei misionară. Pentru a putea fi relevantă şi pentru a putea supraviețui într-o societate secularizată şi pluralistă, Biserica trebuie mai întâi de toate să se concentreze asupra misiunii interne, adică asupra problemelor cu care creștinii se confruntă în viața lor eclesială dar şi socială, fapt care constituie premisa absolut necesară pentru misiunea externă a Bisericii. Astfel, prima etapă în implicarea misionară a creştinilor trebuie să pornească de la conştientizarea problemelor societății post moderne şi a celor cu care Biserica se confruntă în contextul globalizării şi secularizării actuale. În acest sens, în ceea ce urmează două mari teme vor fi dezbătute şi anume: secularismul şi criza liturgică a lumii moderne. Liniile directoare ale unei astfel de misiuni interne a Bisericii pot fi găsite în scrierile părintelui Alexander Schmemann, un valoros cercetător şi istoric liturgist şi totodată un remarcabil misionar şi un exeget al cultului şi spiritualitătii ortodoxe, care de-a lungul vieții sale, trăind într-o varietate de tipare şi medii culturale şi religioase, a reuşit să identifice şi să ofere soluţii la problemele mari cu care Ortodoxia se confruntă în societățile moderne contemporane. Rezultatele analizelor sale, aplicate contextului european actual, dar şi soluțiile propuse de el sunt de o actualitate perenă. Secularismul societății şi criza liturgică a Bisericii sunt în opinia marelui liturgist contemporan cele două mari piedici în calea impactului misionar al Ortodoxiei în lumea zilelor noastre.

${ }^{3}$ Marcel Gauchet, Ieşirea din religie. Parcursul laicității, traducere din limba franceză de Mona Antohi, Bucureşti, Editura Humanitas, 2006, p.9. 


\section{Secularismul: o nouă erezie contemporană}

Format şi consacrat ca teolog al exilului, părintele Schmemann s-a confruntat în mod direct cu cultura europeană modernă secularizată, caracterizată de ascensiunea pozitivismului şi apariţia existenţialismului, dar şi cu creştinismul apusean, aflat într-o criză de identitate profundă datorită depărtării de tradiția Bisericii primare, marele liturgist rus a încercat în scrierile sale sub formă de eseu teologic sau meditaţii şi reflecții subiectiv-personale, să atragă atenția asupra problemelor teologice dogmatice, liturgice şi spirituale cu care sa confruntat Biserica vremii sale. Reflexille sale sunt extrem de pertinente şi extrem de actuale. Problema centrală a fost pentru părintele Schmemann identificarea unei „căi” a Ortodoxiei „într-o lume radical diferită de cea care a modelat mentalitatea şi forma ideilor noastre şi toată viața noastră ca Ortodoxie, într-o lume adânc marcată de crize spirituale care dobândesc, cu trecerea anilor, dimensiuni universale?"4

Cum ar trebui să fie Ortodoxia într-o astfel de lume a modernității? Primul imperativ misionar este pentru părintele Schmemann înţelegerea şi conştientizarea problemelor pe care secularismul le generează mai întâi în societate şi apoi în Biserică. Marele teolog foloseşte noțiunea de „secularism” ca o categorie critică pentru a descrie cultura apuseană. $\mathrm{O}$ cultură seculară este una care a compartimentat şi a banalizat religia şi nu mai ia Biserica în serios. În timp ce Bisericile mai pot încă să prospere în plan instituțional sau lumesc într-o epocă seculară, criteriile pe care ele se bazează nu sunt cele ale credinței creştine, ci sunt derivate de altundeva, ceea ce dă naştere unui creştinism pur nominal sau formal, sau mai bine spus unui creştinism nou, deviat. Părintele Schmemann consideră că problema „profundă şi amenințătoare” cu care se confruntă Biserica Ortodoxă este ,aceea a unei capitulări progresive în favoarea secularizării viziunii despre lume şi viață”. „Viziunea

\footnotetext{
${ }^{4}$ Alexander Schmemann, Biserică, lume, misiune, traducere din limba engleză de Elena Vinţeler, Alba Iulia, Editura Reîntregirea, 2006, p. 16.
} 
despre Dumnezeu, om şi viaţă revelată în credința ortodoxă", redusă în mod deplorabil „la simboluri superficiale, care produc iluzia apartenenței la „credința străbună”, maschează capitularea progresivă a „vieții adevărate” în fața imensei erezii apusene: secularismul; capitulare nu numai a vieții seculare, ci şi a vieții Bisericii"s.

În ciuda acestei aparente disocieri a secularismului de creştinism, părintele Schmemann arată că în mod paradoxal secularismul supraviețuieşte bazându-se pe concepte derivate la origine din creştinism: „secularismul trebuie, într-adevăr recunoscut ca un fenomen „creştin”, ca urmare a unei revoluții creştine. El poate fi explicat doar în contextul istoriei şi punctul lui de plecare îl constituie întâlnirea dintre Atena şi Ierusalim" ". Marele teolog rus era conştient că secularizarea a apărut ca rezultatul conflictului dintre credințe diferite, nu dintre credință şi necredință̌ ${ }^{7}$. De aceea el afirmă că „,secularismul este „,copilul vitreg” al creştinismului, aşa cum sunt, în ultimă instanță, toate ideologiile secularizate care domină astăzi lumea, iar nu - aşa cum pretind apostolii apuseni ai acceptării de către creştini a secularismului - un copil legitim. El este o erezie. Erezia însă este întotdeauna deformarea, exagerarea şi deci mutilarea a ceva adevărat, afirmarea unei „preferințe” (airesis înseamnă „alegere” în limba greacă), alegerea unui element în dauna celorlalte, spargerea catolicității Adevărului"s.

Această „deformare oncologică” a vieții creştine necesită în primul rând o conştientizare din partea Bisericii şi discernământ ca „printr-un efort de înțelegere, această nouă erezie să poată fí, în cele din urmă, învinsă de adevăr"”.

O dată cu adresarea acestei provocări, părintele Schmemann se angajează într-un „efort de înțelegere” a secularismului, postulând faptul că secularismul presupune autonomia lumii. $\mathrm{Cu}$ alte cuvinte,

\footnotetext{
${ }^{5}$ Ibidem, p. 24.

${ }^{6}$ Idem, Pentru viata lumii, traducere de pr. prof. dr. Aurel Jivi, București, EIBMBOR, , 2001, p. 139.

${ }^{7}$ Mircea Platon, Cine ne scrie istoria?, Iaşi, Editura Timpul, 2007, p. 191.

${ }^{8}$ Pr. Alexander Schmemann, Pentru viața lumii ..., p. 157.

${ }^{9}$ Ibidem, p. 158.
} 
secularismul, bazându-se pe dihotomia sacru/secular, exilează sacrul la o singură sferă şi astfel neagă caracterul sacramental al întregii lumii. Secularismul nu este antireligios, pentru că el are un „loc” definit pentru religie, dar religiei i se refuză puterea formării unei viziuni integrate asupra lumii. Religia îşi păstrează un loc relativ nevinovat, deoarece impactul ei asupra tuturor aspectelor vieții este pur şi simplu neutralizat. „Secularistul" poate să fie chiar o persoană religioasă, care frecventează slujbele Bisericii, „se căsătoreşte solemn, casa sa este binecuvântată, îşi îndeplineşte obligațiile sale religioase, totul într-o perfectă bună credinţă ${ }^{\prime \prime 10}$. Totuşi „obligaţiile religioase" ale secularistului nu sunt derivate din credințele mărturisite în Biserică, din ,întruparea, moartea, învierea şi înălțarea lui Hristos", ci mai degrabă din alte filosofii de viață care nu au nimic de-a face cu credința Bisericii. Ca exemplu, părintele Schmemann arată că nu e greu să vezi că multe din valorile cheie aprobate de societate, cum ar fi succesul, siguranța, competiția, poziția socială, belşugul, profitul, prestigiul, ambiția (sub forma succesului echivalat cu bani) sunt în mod direct opuse întregului ethos al Evangheliei. Pentru a elucida definiția dată de el secularismului, părintele Schmemann îl citează pe teologul biblic Will Herberg ${ }^{11}$ : „America pare să fie în acelaşi timp cea mai religioasă şi cea mai seculară dintre națiuni... Fiecare aspect al vieții religioase contemporane reflectă acest paradox: secularism pătrunzător în mijlocul unei religiozități crescute... Afluența membrilor în biserici şi promptitudinea sporită a americanilor de a se identifica pe ei înşişi în termeni religioşi cu siguranță par să stea în contrast cu modul americanilor de a gândi şi a simți în legătură cu chestiunile centrale ale credinței pe care o mărturisesc...Ei gândesc şi trăiesc în termenii unui cadru al realităţii şi valorii străine de credințele religioase pe care le mărturisesc în acelaşi timp". ${ }^{12}$

\footnotetext{
${ }^{10}$ Idem, Problems of Orthodoxy in America. III. The Spiritual Problem, în "St. Vladimir's Theological Quarterly", vol. 9, nr. 4, 1965, p. 173.

${ }^{11}$ Ibidem, p. 174.

${ }^{12}$ Will Herberg, Protestant - Catholic - Jew. An Essay in American Religious Sociology, third edition, The University of Chicago Press, 1983, p. 2-3.
} 
Această nouă religie modernă oferă standarde etice şi un sens al confortului de care are nevoie omul contemporan, însă ei nu i se atribuie puterea de a transforma viața. Secularismul accepta şi cunoaşte existența lui Dumnezeu, însă afirmă în acelaşi timp autonomia existenței umane:

\begin{abstract}
„un secularist concepe lumea ca avându-şi în sine sensul ei şi principiile cunoașterii și acțiunii. El poate, eventual, să-i descopere semnificația în Dumnezeu și Îi poate atribui lui Dumnezeu originea lumii și legile care o guvernează... Cu alte cuvinte, el poate «referi» secularismul său la Dumnezeu și să-1 facă «religios» ... Toate acestea nu schimbă cu nimic «secularitatea» fundamentală a viziunii sale despre om şi lume, în lume fiind înțeles, experiat şi aplicat în proprii termeni imanenți şi pentru propriul scop imanent"13.
\end{abstract}

Lumea este concepută a fi un sfârşit în ea însăşi, în aşa fel încât în imaginația secularistului epifania divină nu îşi găseşte nici un sens. Astfel, în timp ce religia deține doar un mic „loc” în viață, ea continuă să fie un aliat pentru secularism deoarece abandonează sau lasă lumea „seculară” şi profană, „ca total incapabilă de orice comunicare reală cu divinul, de orice transformare şi transfigurare reale" ${ }^{p 14}$.

\title{
2. Efectele secularismului asupra Bisericii: criza liturgică
}

Secularismul ca o erezie a lumii moderne este o mare provocare pentru viața Bisericii. Pentru Părintele Schmemann unul dintre cele mai dureroase „semne ale vremurilor" este faptul că Ortodoxia tinde tot mai mult în societatea actuală să îşi piardă propria ei viziune şi identitate, şi copleşită de materialismul lumii moderne reuşeşte greu să mai fie ,aluatul care să dospească toată frământătura".

Noua situație creată este numită de marele teolog prin termenul

\footnotetext{
${ }^{13}$ Pr. Alexander Schmemann, Pentru viața lumii.., p. 152-153.

${ }^{14}$ Ibidem, p. 164.
} 
generic de „criză liturgică” ${ }^{15}$ şi ea se caracterizează printr-o serie de disfuncții sau anomalii care pot fi astfel sistematizate:

a. Sub influența secularismului cultul Bisericii este redus la un ansamblu de rituri şi ceremonii cu o dublă funcție: ca obiect de adoraţie in sine însuşi şi pentru satisfacerea unor necesităţi practice ale credincioşilor. Biserica a devenit astfel o societate de prestări de servicii religioase ${ }^{16}$, ea a devenit o funcție a cultului.

b. Slujbele sunt rupte de Liturghie şi sunt reduse şi schematizate pentru a oferi cât mai facil ,ajutorul spiritual" pe care îl cer credincioşii. Cultul nu mai sesizat de credincioşi ca o revelare şi o realizare a Bisericii şi ca un mediu de împărtăşire cu Hristos la Cina Împărăţiei cerurilor ci este perceput adesea dintr-o perspectivă pietistă şi individualistă. Criza liturgică bazată pe opoziția dintre cultul public şi cel privat a culminat în epoca contemporană într-o acută şi gravă criză a vieții bisericeşti. Astfel, părintele Schmemann constată că în conştiința credincioşilor distincția între cultul public şi cultul privat răspunde doar unor necesităţi individuale. De pildă, tainele Botezului, Mirungerii şi Cununiei, nemaivorbind de celelalte servicii (recviemuri) şi de slujbele funerare, au căzut în categoria ceremoniilor private. Această distincție între cultul colectiv şi cel privat este generată de $\mathrm{o}$ contradicție cu privire la vechiul şi fundamentalul concept de «cult creştin», ca act public al Bisericii în care nu este şi nu poate fi ceva privat.

c. În interpretarea contemporană a cultului şi în special a Liturghiei Părintele Alexander Schmemann a propus o depăşire a simbolismului analogic-istoric redus la o funcție descriptivă a evenimentelor legate de viața Mântuitorului Iisus Hristos prin întoarcerea la viziunea creştinismului primar asupra Liturghiei experiată ca Taină a lumii viitoare, ca Cina de la masa Împărăției ${ }^{17}$.

\footnotetext{
${ }^{15}$ Idem, Theology and Eucharist, în "St. Vladimir's Theological Quarterly" 4 (1963), pp. 20-23.

16 Idem, Theology and Liturgical Tradition, în Massey Shepherd (ed.), "Worship in Scripture and Tradition", Oxford, Oxford University Press, p. 172. 17 Idem, Euharistia, Taina Impărăției, traducere de Pr. Boris Răducanu, Ed. Anastasia, Bucureşti,1992, pp. 73-74
} 
În opinia sa, criza liturgică se datorează şi unei hermeneutici greşite cu privire la rolul simbolului în cult, care este văzut ca o reprezentație sau o ilustrație sacră ${ }^{18}$ având doar o valoare descriptivistorică. Simbolul este însă un mod de prezență şi de lucrare a lui Dumnezeu în şi prin intermediul materiei văzute, a actelor cultice, şi de aceea el are o valoare revelatorie, epifanică de a uni pe Dumnezeu cu omul. În acest sens, Liturghia este interpretată ca o serie de lucrări sacramentale, numite Taine prin care omul se uneşte cu Dumnezeu şi participă la viața divină.

d. Pierderea dimensiunii relaţiei personale între membrii Bisericii ceea ce a dus la dispariţia parohiei ca şi comuniune în Hristos dintre credincioşii. Parohia a devenit o instituție seculară, care este bine organizată şi eficientă, dar este „,a-liturgică”, ea nu mai are la baza ei împărtăşirea de Hristos şi nici filantropia creştină primară. Odată cu faptul că Liturghia nu mai pătrunde în totalitatea vieții şi nu îşi mai afirmă menirea de a-1 pregăti pe om pentru viaţa viitoare, Biserica a pierdut abilitatea de a comunica propria sa viziune asupra vieții şi devine irelevantă şi incapabilă de a schimba lumea dar şi de a se apăra in fața ereziei secularismului.

Toate aceste simptome sunt însă mascate de un „optimism oficial obligatoriu" arătat în primul rând într-o frenezie faraonică a zidirii de noi locaşuri de cult. Părintele Schmemann vorbeste astfel despre o Ortodoxie seculară în care pentru a avea succes pe plan bisericesc se consideră că trebuie „să construieşti biserici mai mari şi mai bune şi tot felul de facilități, să ții comunitatea ocupată şi fericită, să oferi slujbe ordonate, să afirmi constant că Ortodoxia este credința adevărată". ${ }^{19}$ Biserica suferă şi ea ca şi societatea o mutație devinind o societate de prestări de servicii religioase, fără a mai afirma cu tărie imperativul schimbării vieții şi al pregătirii pentru eshaton. Toate acestea generează un „tragic nominalism, care pătrunde întreaga viață a Bisericii şi o împiedică să-şi îndeplinească

18 David W. Fagerberg, Theologia Prima. What is Liturgical Theology?, Hillenbrand Books, Chicago/Mundelein, Illinois, 2004, p. 88.

${ }^{19}$ Pr. Alexander Schmemann, Problems of Orthodoxy in America: III. The Spiritual Problem...., p. 171. 
misiunea esențială, sarcina de a judeca, evalua, inspira, schimba şi transforma toată viața omului, de a genera acea tensiune creativă între ea şi lume, care o transformă în ,,sarea pământului”20.

Marele liturgist rus atrage atenția că nici clerul nu este în nici un caz imun la secularismul cultural pătrunzător şi poate fi primul care propagă filozofia secularistă a religiei. Tendinţa uşoară de a pune accentul pe criteriile externe rezultă într-o reducere a Ortodoxiei: "la o canonicitate formală sau la corectitudine liturgică

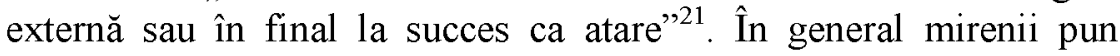
accentul pe criterii exterioare, socotind că modul ortodox de viață cere frecventarea regulată a slujbelor, păstrarea unui minimum de reguli externe, contribuția financiară față de Biserică, pe scurt o viață care constă în principal din îndeplinirea datoriilor religioase formale ale unei persoane. Religia este înțeleasă ,în termenii unor „tabuuri” sacre, prescripții şi obligații legale, corectitudine rituală şi „validitate" canonică"22.

Când Ortodoxiei i se ignoră puterea de a transforma în mod real o persoană din interior, atunci ea uşor este cuprinsă de o logică seculară pe care Pr. Schmemann o denunță cu următoarele cuvinte: „cineva nu poate fi ortodox în Biserică şi ,secularist” în viaţă. Mai degrabă sau mai târziu va deveni secularist şi în Biserică"23. Biserica Ortodoxă devine într-o societate seculară o „Biserică de duminică Viaţa liturgică care este limitată la duminici şi alte câteva zile obligatorii, cum ar fi Crăciunul sau Paştile, este simptomatică pentru declinul sau căderea din pietatea liturgică, care odinioară intervenea mult mai vital în alcătuirea şi desfăşurarea vieții de zi cu zi. „Sărbătorile şi ajunurile lor, „tristețea strălucitoare” a slujbelor Postului, frumusețea cerească unică a ciclului mariologic, căldura, comemorarea aproape personală a sfinților, crescendo-ul prelung şi

${ }^{20}$ Idem, Biserică, lume, misiune ..., p. 25.

${ }^{21}$ Idem, Problems of Orthodoxy in America. III. The Spiritual Problem..., p. 175.

${ }^{22}$ Idem, Pentru viața lumii, p. 161.

${ }^{23}$ Idem, Problems of Orthodoxy in America. III. The Spiritual Problem..., p. 176. 
solemn al Săptămânii Mari - toate acestea sunt virtual absente din viața liturgică reală" ${ }^{\prime 24}$.

La nivelul parohiei un exemplu foarte practic al acestei pierderi este reflectat în administrarea Bisericiii ${ }^{25}$. Dacă „conținutul” administrării Bisericii înseamnă a veghea la succesul material al parohiei, de ce ar trebui ca un preot să fie mai competent decât un grup de profesionişti? Părintele Schmemann observă că această chestiune arată faptul că atât clerul, cât şi mirenii au acceptat ideile seculare de administrație. Ce înțelege părintele Schmemann prin aceasta? El afirmă că acest sector al vieții Bisericii, administraţia şi management-ul economic, văzut în termeni strict seculari, nu a fost relaționat cu scopul Bisericii aşa cum este revelat în Liturghie. De exemplu, banii şi ofranda rămân fără legătură cu Euharistia şi Euharistia cu întreaga viață. Totuşi este datoria preotului să transforme ofranda sau darul într-un act religios, deoarece „el oferă jertfa Bisericii lui Dumnezeu" ${ }^{\text {"26 }}$.

Totuşi părintele Schmemann afirmă că parohia aşa cum există ea astăzi, cu ,funcționari, decizii, finanțe, proprietăți, datorii, intâlniri, alegeri etc." este mai degrabă un fenomen recent. Ceea ce creştinul ortodox consideră astăzi ca fiind normativ în Biserică, nu a fost perceput întotdeauna astfel. Timp de secole Biserica a fost centrul religios al unei mai mult sau mai puține "naturale" comunități a unui sat sau al unui district al unui oraş. „În interiorul acestei comunităti Biserica nu avea alte funcții, ci doar aceea de a face în mod literal pe Hristos prezent: în predică, sacramente, cult, educație - şi de a face viața enoriaşilor ca şi creştini pătrunsă de Hristos, atât cât este posibil"27. Rolul primordial al parohiei era exclusiv euharistic, la momentul apariției acestei forme de organizare bisericească ea constituind ,produsul unei nevoi" determinate atât de creşterea bruscă a numărului creştinilor, cât şi de necesitatea

${ }^{24}$ Idem, Problems of Orthodoxy in America. II. The Liturgical Problem, în "St. Vladimir's Theological Quarterly", vol. 8, nr. 4, 1964, p. 164.

${ }^{25}$ Ibidem, p. 174.

${ }^{26}$ Ibidem.

${ }^{27}$ Ibidem, p. 182. 
săvârşirii permanente a Euharistiei în condițiile în care episcopii nu mai puteau face față situațiilor existente. Evoluția şi dezvoltarea ulterioară a sistemului bisericesc parohial nu s-a îndepărtat în esență de această caracteristică şi funcție a sa, doar perceperea sa de către credincioşi (de multe ori chiar şi de către clerici) s-a modificat. "Comuniunea în Hristos" ca şi particularitate a parohiei a rămas validă. „În tradiția ortodoxă parohia există în lume nu ca o corporație religioasă pentru dirijarea şi realizarea unor forme şi convenții religioase, ci ca o comunitate integrală, independentă şi neinfluențată de societățile lumeşti, de viața şi scopurile lor. Fiindcă parohia ca Biserică „,̂intr-un loc" îşi are propria ei viaţă, propriul ei scop"28.

În concepția părintelui Schmemann „organizația parohială” a înlocuit Biserica. Clerul şi mirenii sunt în mod ironic parte a unui sistem pe care ei înşişi l-au creat: „ei sunt literal zdrobiți de o construcție în care ei au investit atât de mult din energia, sufletul şi dragostea lor"29. Dat fiind faptul că în interiorul parohiei există un eşec în a încorpora viziunea ortodoxă despre lume, care este transmisă în Liturghie, cu atât mai mult va fi dificil ca aceasta să aibă vreun impact asupra altor aspecte ale vieții de familie, profesiei, educației şi recreerii. Liturghia a devenit „o maşină neconectată la roți, care produce o energie care nicăieri nu devine mişcare, lumină sau căldură" ${ }^{30}$ Părintele Schmemann rezumă astfel transformarea care a avut loc în înțelegerea fundamentală a Liturghiei:

„Chestiunea care stă la baza întregii experiențe liturgice a
Ortodoxiei, «ce descoperă aceasta în legătură cu mine şi viața
mea, ce înseamnă aceasta pentru activitatea mea și relația mea
cu oamenii, natura şi timpul», este înlocuită puțin câte puțin de o
chestiune complet diferită: "«cât de mult din Liturghie este
nevoie pentru a mă pune pe mine într-o «stare (poziție) bună»?
Și unde religia devine o problemă de obligație şi de bunăstare,

${ }^{28}$ Pr. Gheorghios Metallinos, Parohia - Hristos in mijlocul nostru, traducere de pr. Prof. Ioan I. Ică, Editura Deisis, Sibiu, 2004, p. 39.

${ }^{29}$ Ibidem, p. 186.

${ }^{30}$ Idem, Problems of Orthodoxy in America. II. The Liturgical Problem.., p. 175 . 
inevitabil toate chestiunile privind practicile «bune»" şi «rele» dobândesc un fel de independență față de implicațiile lor morale, existenţiale, cu adevărat religioase" 31 .

Ceea ce încă de la început era rodul real al Liturghiei, adică „amestecul unic de bucurie şi pocăinţă", care provoacă şi transformă întreaga viaţă a unei persoane, acum este absent. Din punct de vedere strict formal „Liturghia este încă centrul vieții Bisericii, indiscutabil şi necontestat. Dar de fapt este un centru fără periferie, o inimă fără nici un control asupra circulației sângelui, un foc fără nimic de purificat şi consumat, deoarece acea viață care trebuie cuprinsă de ea a fost satisfăcută cu ea însăşi şi a ales alte lumini care să o ghideze şi să-i dea formă" 32 .

Pierderea relevanței Liturghiei pentru viața noastră actuală a afectat de asemenea şi raportarea persoanei ortodoxe la păcat. Înţelegerea păcatului nu mai este înrădăcinată într-o ,,viziune totală a vieții descoperită în cult, ci altundeva - în „bunul simț”, regula de aur, idealul moderației..."33 . Părintele Schmemann afirmă că în trecut creştinul ortodox nu era mai moral, dar „cel puțin el ştia că este un păcătos" ${ }^{\prime 34}$. Dacă cineva crede că opusul păcatului este urmarea unui set de reguli şi obligații impuse de vreo autoritate bisericească mai mare, atunci nu va reuşi să înțeleagă rădăcinile mai adânci ale păcatului ca mod de viață, ca orientare, o existență înaintea faptelor. Din acest motiv „este, într-adevăr, mult mai uşor să trăieşti şi să respiri în cadrul unor distincţii clare între sacru şi profan, natural şi supranatural, pur şi simplu; este uşor să înţelegi religia în termenii unor «tabuuri» sacre, prescripții şi obligaţii legale, corectitudine rituală şi «validitate» canonică”3’

În fața secularismului societății moderne, părintele Schmemann afirmă că Ortodoxia a răspuns în două moduri mutual

${ }^{31}$ Ibidem.

${ }^{32}$ Ibidem.

${ }^{33}$ Ibidem, p. 165.

${ }^{34}$ Ibidem.

${ }^{35}$ Idem, Pentru viața lumii, p. 161. 
exclusive: pe de o parte prin negativismul pesimist al „profetului super-ortodox al destinului apocaliptic" şi, pe de altă parte, prin „pozitivismul optimist al apuseanului entuziast al creştinismului secular" ${ }^{\prime 36}$. Prima abordare include pe cei care resping „europenizarea” Ortodoxiei, în timp ce a doua abordare renunță la mult din Ortodoxie ,în numele integrării europene”. Superortodoxul se retrage într-un ,trecut creat artificial” şi crede că numai printr-o astfel de retragere poate Biserica să-şi păstreze credința în fața apostaziei. Aceşti ortodocşi conservativi în mod profund sunt ataşaţi de tot ceea ce este acoperit de strălucirea, slava pravoslavnică a trecutului fără a încerca o înțelegere a provocărilor prezentului. Cealaltă categorie de creştini deschişi modernității nu fac decât să mărturisească predarea lor totală în fața secularismului contemporan.

Părintele Schmemann susține că ambele grupuri fac astfel dovada faptului că nu înțeleg menirea adevărată a Ortodoxiei care trebuie să fie ,într-o tensiune creativă cu lumea în care trăieşte" care trebuie să chestioneze toate „valorile” şi modurile de viaţă ale lumii şi să le reevalueze şi să le schimbe, punându-le în raport cu Adevărul Absolut descoperit în Biserică ${ }^{38}$. Părintele Schmemann consideră că ceea ce este nevoie să facem nu înseamnă nici să acceptăm, nici să respingem lumea în care trăim, ci pur şi simplu să o înfruntăm ca şi creştini ortodocşi. A înfrunta lumea înseamnă a lega întregul vieții noastre de credință (a pune întregul vieții noastre în raport cu credința):

„ideea centrală și atotcuprinzătoare şi inspirația Ortodoxiei că întreaga viață nu numai că aparține lui Dumnezeu, ci trebuie făcută asemenea cu Dumnezeu și centrată în jurul lui Dumnezeu, transformată în comuniune cu Dumnezeu şi, astfel nici un „sector" al activității şi creativității umane, fie cel mai „secular" sau „profan”, nu poate fi neutru, nici incapabil de a fi sanctificat, i.e. transformat în comuniune cu Dumnezeu",39.

\footnotetext{
${ }^{36}$ Ibidem, p. 160.

${ }^{37}$ Idem, Problems of Orthodoxy in America. II. The Liturgical Problem, p. 184. ${ }^{38}$ Ibidem.

${ }^{39}$ Ibidem, p. 173.
} 
Astfel Ortodoxia revendică necesitatea unui mod de viață atotcuprinzător, o „viziune totală şi cuprinzătoare asupra lumii” ${ }^{40}$.

\section{Redescoperirea dimensiunii liturgice a persoanei şi existenței umane - soluția pentru depăşirea efectelor secularismului şi pentru ieşirea din criza liturgică contemporană}

Părintele Schmemann consideră că unica soluție pentru depăşirea tuturor problemelor generate de pătrunderea secularismului în societatea contemporană dar şi în Biserică este revenirea la viețuirea şi credinţa creştinilor primelor veacuri pentru care cel mai important eveniment al existenței lor cotidiene era participarea la Jertfa Euharistică. În opinia sa, prin Sfânta Liturghie, Biserica se afirmă ca Trup al lui Hristos şi ca Taină a Împărăţiei cerurilor şi tot prin ea Hristos îi uneşte cu Sine pe toți în misiunea, jertfa şi învierea Lui, de aceea Sfânta Liturghie este şi locul prin excelenţă unde creştinii se pregătesc pentru misiune. Căci a fi în comuniune cu Hristos cel răstignit şi înviat înseamnă a fi pătruns de iubirea lui față de lumea pentru mântuirea căreia El şi-a dat viaţa şi a te angaja în slujba înfăptuirii Împărăției lui Dumnezeu.

Secularizarea vieții bisericeşti a generat o rupere a Euharistiei de celelalte Taine, o denaturare a caracterului eshatologic al cultului şi o exagerare a simbolismului şi a formelor externe ale slujbelor bisericeşti. Pentru a ieşi din această situație, pentru ca Ortodoxia să îşi găsească din nou avântul ei misionar şi pentru ca ea sa devină din nou „calea spre Împărăție”, Părintele Schmemann propune următoarele soluții:

1. Sfânta Liturghie trebuie să fie Taina Bisericii prin excelență - prin care se realizează şi se desăvârşeşte Biserica şi prin care credincioşii participă real la Cina euharistică a Împărăției cerurilor. Biserica se manifestă şi realizează prin Taina Sfintei Euharistii, dar ea are şi un rol misionar: acela de a se extinde în lume şi de a

\footnotetext{
${ }^{40}$ Ibidem.
} 
cuprinde în mod real şi actual întreaga umanitate în trupul mistic al lui Hristos Sfânta Liturghie nu trebuie să sufere o instrumentalizare seculară care o transformă într-un mijloc de rezolvare a unor necesități materiale şi spirituale ale credincioşilor.

2. Sfânta Euharistie trebuie să fie din nou legată de toate Sfintele Taine ale Bisericii fiind împlinirea şi încoronarea lor;

3. Depăşirea în interpretarea cultului şi a Liturghiei a simbolismului analogic-istoric redus la o funcție descriptivă a evenimentelor legate de viața Mântuitorului Iisus Hristos prin întoarcerea la viziunea creştinismului primar asupra Liturghiei experiată ca Taină a lumii viitoare, ca Cina de la masa Împărăției.

3. Biserica trebuie să fie percepută de toți credincioşii ca fiind Taina divino-umană în care elementul uman compus din clerici şi laici constituie o structură dialogică bazată pe conslujire (adunarea euharistică, rugăciunile sunt rostite la plural, dialogul liturgic dintre preot şi credincioşi, şi revenirea la unele practici din Biserica primară: sărutarea păcii - aducerea şi oferirea darurilor de credincioşi);

4. Pentru ca Sfânta Liturghie să-şi poată atinge cu adevărat scopul ei este nevoie să se revină la practica veche a rostirii rugăciunilor preotului cu glas tare; să fie urmărită prin cateheze întelegerea corectă de către preoți şi credincioşi a Liturghiei ca Taină a Împărăţiei cerurilor, să fie promovată participarea prin implicare a tuturor credincioşilor în săvârşirea Sfintei Liturghii, prin aducerea darurilor, prin cântările liturgice şi în final prin împărtăşirea euharistică „cu cugetul curat”; să fie adăugată la această împărtăşire euharistică şi împărtăşirea duhovnicească de Hristos prin virtuți şi rugăciune, prin care credincioşii pot conştientiza şi simţi prezența lui Hristos.

5. Redescoperirea dimensiunii social umanitare a Sfintei Liturghii. Unirea cu Hristos şi unirea cu săracii sunt două aspecte ale unei unice realități. Milostenia este atât criteriu de acces la Taina Sfintei Euharistii cât şi consecinţă a împărtăşirii cu Trupul lui Hristos. Unirea cu Hristos este intrarea într-un mod de viață caracterizat de logica dăruirii de Sine a altruismului creștin dar şi a 
mărturisirii adevărului Evangheliei lui Hristos.

Individualismul, ca egoism al lumii seculare moderne şi Euharistia se exclud reciproc. În general se subliniază ideea unei continuităţi dintre Liturghie şi viaţa cotidiană, dar sintagma Liturghie după Liturghie riscă să păstreze tragica separare între două compartimente ale modului de viață creştin şi anume viaţa liturgică şi viaţa socială a Bisericii.

Socialul şi Liturgicul trebuie să alcătuiască o unitate între ele iar în acest sens trebuie să fie înțeleasă şi interpretată expresia: „Liturghie după Liturghie”. Nu există decât o singură Liturghie, o singură participare la iubirea Sfintei Treimi, un singur dialog de iubire între Dumnezeu şi om care cuprinde toate aspectele vieții noastre şi un singur imperativ al mărturisirii adevărului Evangheliei. Aşadar, toate actele vieții pământeşti nu reprezintă o faptă bună oarecare, una dintre multele pe care săvârşindu-le ne câştigăm vreun merit sau o vrednicie înaintea lui Dumnezeu, ci ea este însuşirea şi gustarea vieții celei noi a lui Hristos, care ne preschimbă şi ne preface ontologic pe fiecare din noi. Intrat în acest circuit al iubirii jertfelnice al Sfintei Treimi omul simte că toate sunt daruri şi că ele trebuie întoarse Dăruitorului şi înțelege prin smerenie că nu face nimic altceva decât ,ceea ce este dator să facă” (Luca 17,10).

\section{Concluzii}

Contextul religios, cultural, social şi istoric actual cere imperios ca Ortodoxia să fie fermentul din mijlocul lumii care „să dospească toată frământătura". Provocările modernității sunt majore şi se răsfrâng pe toate palierele vieții şi în toate domeniile de activitate. Ele cer o renaştere a Teologiei ortodoxe, singura care poate da răspunsurile ultime la problemele majore cu care se confruntă societatea modernă consumistă. De aceea Teologia trebuie să aleagă calea înnoirii patristice şi liturgice, trăind din duhul Tradiției apostolice şi explicându-l într-un mod adaptat cerințelor vremii.

În lumea actuală marcată de pluralismul şi democrația 
egoismului şi a afirmării umanismului, Teologiei liturgice îi revine o sarcină misionară dificilă: Dacă Sfânta Liturghie devine sursa a toată teologhisirea dar şi a vieții individuale a fiecărui creştin, atunci răspunsul Bisericii la toate problemele modernității va fi unul viu, profund, personal şi relevant. Teologia care nu are ca izvor Liturghia şi nu are imprimată în ea experiența personală ca rodire a vorbirii cu Dumnezeu riscă extremele scolasticismului (dogmatic), ale ritualismului (liturgic), sau ale formalismului (etic). Criza profundă a societății moderne poate fi depăşită doar printr-o revigorare a Teologiei prin orientarea şi centrarea ei pe viața liturgică a Bisericii. Doar astfel discursul teologic modern poate deveni unul pastoral, mistic şi relevant pentru omul secolului al XXI-lea.

\section{Bibliografie}

1. Davie, Grace, Religion in Britain Since 1945: Believing Without Belonging, Oxford, Basil Blackwell, 1994.

2. Fagerberg, David W., Theologia Prima. What is Liturgical Theology?, Illinois Hillenbrand Books, Chicago/Mundelein, 2004.

3. Gauchet, Marcel, Ieşirea din religie. Parcursul laicității, traducere din limba franceză de Mona Antohi, București, Editura Humanitas, 2006.

4. Herberg, Will, Protestant - Catholic - Jew. An Essay in American Religious Sociology, third edition, The University of Chicago Press, 1983.

5. Metallinos, Gheorghios, Parohia - Hristos in mijlocul nostru, traducere de pr. Prof. Ioan I. Ică, Sibiu, Editura Deisis, 2004.

6. Platon, Mircea, Cine ne scrie istoria?, Iaşi, Editura Timpul, 2007.

7. Schmemann, Alexander Biserică, lume, misiune, traducere din limba engleză de Elena Vințeler, Alba Iulia, Editura Reîntregirea, 2006.

8. Idem, Pentru viața lumii, traducere de pr. prof. dr. Aurel Jivi, Bucureşti, EIBMBOR, 2001.

9. Idem, Problems of Orthodoxy in America. II. The Liturgical Problem, în "St. Vladimir's Theological Quarterly", vol. 8, nr. 4, 1964, pp. 164-185.

10. Idem, Problems of Orthodoxy in America. III. The Spiritual Problem, în "St. Vladimir's Theological Quarterly", vol. 9, nr. 4, 1965, pp. 171-193.

11. Idem, Theology and Eucharist, în "St. Vladimir's Theological Quarterly" 4 (1963), pp. 20-23. 
12. Idem, Theology and Liturgical Tradition, în Massey Shepherd (ed.), "Worship in Scripture and Tradition", Oxford, Oxford University Press, pp. $165-178$

13. Idem, Euharistia, Taina Impărăției, traducere de Pr. Boris Răducanu, București, Ed. Anastasia, 1992. 